\title{
Menumbuhkan Minat Berwirausaha Mahasiswa Melalui Kecerdasan Emosional
}

\author{
Hindra Wanto ${ }^{\mathrm{a}, 1}$, Siti Halimah ${ }^{\mathrm{a}, 2}$, Mahmu'ddin ${ }^{\mathrm{a}, 3}$ \\ ${ }^{a}$ STKIP Muhammadiyah Sampit, Kalimantan Tengah, Indonesia \\ ${ }^{1}$ hindrawanto69@gmail.com \\ ${ }^{2}$ siti_halimah@stkipmsampit.ac.id \\ ${ }_{3}^{3}$ mahmudin@stkipmsampit.ac.id
}

ABSTRACT

Article history:

Received : 2018-05-28

Revised : 2018-06-29

Accepted : 2018-06-30

Keywords:

Interest

Entrepreneurship student

Emotional intelligence
This study was conducted to determine the effect of emotional intelligence on students' entrepreneurship interest at semester VI Department of Information Systems Study Program Information System of Sampit Darwan Ali University Academic Year 2016/2017. This study used quantitative methods using survey technique. The subjects of the study were 92 students. Data collection techniques use a questionnaire fulfilled the requirements of validity and reliability. The technique of validity test used correlated item-total correlation and reliability test of Cronbach's alpha. In this study, the instrument used was questionnaire by using the likert scale. The data analysis technique used was a simple linear regression analysis fulfilled the analytical prerequisite, such as the test of normality, linearity and autocorrelation. This study revealed that emotional intelligence was moderate $70.65 \%$ and entrepreneurship interests were also moderate $67.39 \%$. The result of analysis showed that there was an influence of emotional intelligence to student entrepreneur interest. Coefficient of determination ( $\mathrm{r} 2)$ was 0.265 . It meant that emotional intelligence could foster interest in entrepreneurship student.

Copyright $(92018$ IAIN Palangka Raya. All rights reserved.

\section{Pendahuluan}

Pendidikan merupakan usaha sadar dan terencana untuk mewujudkan suasana belajar dan proses pembelajaran agar peserta didik secara aktif mengembangkan potensi dirinya untuk memiliki kekuatan spiritual, pengendalian diri, kepribadian, kecerdasan, akhlak mulia, serta keterampilan yang diperlukan dirinya, masyarakat, bangsa dan negara. Pendidikan berfungsi mengembangkan kemampuan dan membentuk watak serta peradaban bangsa yang bermartabat dalam rangka mencerdaskan kehidupan bangsa, bertujuan untuk berkembangnya potensi peserta didik agar menjadi manusia yang beriman dan bertakwa kepada Tuhan Yang Maha Esa, berakhlak mulia, sehat, berilmu, cakap, kreatif, mandiri, dan menjadi warga negara yang demokratis serta bertanggung jawab.(6)

Mahasiswa merupakan komponen pendidikan yang menempuh pendidikan di DOI: 10.23971/jsam.v14i1. perguruan tinggi. Mahasiswa menempati posisi sentral, berada di usia pertengahan yang mulai mengaktualisasikan dirinya dengan kehidupan. Menempuh pendidikan di perguruan tinggi menjadikan mahasiswa dipandang berbeda oleh masyarakat pada umumnya. Mahasiswa dianggap memiliki kualitas, ilmu pengetahuan, wawasan yang luas serta mengikuti perkembangan sains dan teknologi. Dengan bekal dan pengalaman yang dimiliki mahasiswa menjadi harapan bagi bangsa dan negara, dimana mahasiswalah pemegang estapet kepemimpinan atas pendahulunya sehingga menjadikan mahasiswa sebagai pokok tumpuan perhatian bagi keberlangsungan masa depan bangsa dan negara. Mahasiswa memiliki peran penting sebagai agen perubahan (agent of change) bagi tatanan kehidupan yang secara realistis dan logis diterima oleh masyarakat. Mampu menerapkan dan mengaplikasikan pengetahuan yang telah diperolehnya selama menempuh proses pembelajaran di perguruan

W : http://e-journal.iain-palangkaraya.ac.id/index.php/jsam E : Jsam.iainpky@gmail.com 
tinggi, sehingga dapat memberikan manfaat bagi masyarakat luas.

Layaknya komponen manusia lainnya mahasiswa juga memiliki kebutuhan yang harus dipenuhi. Dalam pemenuhannya pun berbeda-beda baik melalui orang tua maupun dengan penghasilan sendiri yang didapat dengan bekerja. Setelah menyelesaikan perkuliahan mahasiswa diharapkan tidak menjadi beban negara dengan menambah jumlah pengangguran yang ada di Indonesia. Menurut Kepala Badan Pusat Statistik Suryamin sejak Februari 2015 jumlah pengangguran di Indonesia mencapai 7,4 juta, dimana pengangguran dengan pendidikan sarjana berjumlah 395.160 orang.(11)

Melihat realitas tersebut sudah semestinya mahasiswa terdorong untuk menciptakan kemandirian ekonomi yang memenuhi kebutuhan melalui penghasilan sendiri sejak dini dan tidak mengantungkan harapan semata-mata setelah lulus kuliah hanya ingin menjadi karyawan, apalagi hanya berpangku tangan kepada orang tua. Menurut Steinhoff dan Burgess yang dikutip oleh Muhammad Sadudin dalam skripsinya menjelaskan bahwa mahasiswa harus menumbuhkembangkan kreativitas dalam membangun kemandirian ekonomi melalui kecerdasan yang dimiliki, serta didorong oleh minat berwirausaha yang tinggi. dalam menggunakan sumber daya finansial, bahan mentah dan tenaga kerja untuk menghasilkan sesuatu yang baru. Penyebab rendahnya minat berwirausaha dipengaruhi oleh rendahnya sifat percaya diri, mental yang lemah dan rasa putus asa terhadap hambatan dalam wirausaha.(10)

Berdasarkan uraian di atas, maka penulis merasa tertarik untuk meneliti dan merumuskan masalah apakah ada Pengaruh Kecerdasan Emosional Terhadap Minat Berwirausaha Mahasiswa Semester VI Jurusan Sistem Informasi Program Studi Sistem Informasi Universitas Darwan Ali Sampit Tahun Akademik 2016/2017.

\section{Kajian Pustaka}

Kecerdasan emosional adalah "kemampuan seperti kemampuan untuk memotivasi diri sendiri dan bertahan menghadapi frustasi, mengendalikan dorongan hati dan tidak melebih-lebihkan kesenangan, mengatur suasana hati dan menjaga agar beban stres tidak melumpuhkan kemampuan berpikir, berempati, dan berdoa".(7) Kecerdasan emosional adalah "kemampuan untuk merasa".(1) Kecerdasan emosional adalah "satu unit perilaku, kemampuan, keyakinan, dan nilai-nilai yang kompleks, yang membuat manusia mampu memahami imajinasi dan tugas-tugasnya dengan sukses sesuai dengan pilihannya".(2)

Berdasarkan pengertian diatas, dapat disimpulkan bahwa kecerdasan emosional adalah kemampuan mengenali perasaan kita sendiri dan perasaan orang lain, kemampuan memotivasi diri sendiri, kemampuan mengelola emosi dengan baik pada diri sendiri dan mengenali dengan baik emosi orang lain.

Faktor-Faktor yang Mempengaruhi Kecerdasan Emosional.(7)

\section{Lingkungan Keluarga.}

Kehidupan keluarga merupakan sekolah pertama dalam mempelajari emosi. Peran serta orang tua sangat dibutuhkan karena orang tua adalah subyek pertama yang perilakunya diidentifikasi, diinternalisasi yang pada akhirnya akan menjadi bagian dari kepribadian anak. Kecerdasan emosi ini dapat diajarkan pada saat anak masih bayi dengan contoh-contoh ekspresi. Kehidupan emosi yang dipupuk dalam keluarga sangat berguna bagi anak kelak di kemudian hari, sebagai contoh yaitu melatih kebiasaan hidup disiplin dan bertanggung jawab, kemampuan berempati, kepedulian, dan sebagainya.

\section{Lingkungan Non Keluarga.}

Dalam hal ini adalah lingkungan masyarakat dan lingkungan penduduk. Kecerdasan emosi ini berkembang sejalan dengan perkembangan fisik dan mental anak. Pembelajaran ini biasanya ditunjukkan dalam aktivitas bermain anak seperti bermain peran. Anak berperan sebagai seseorang diluar dirinya dengan emosi yang menyertainya sehingga anak akan mulai belajar mengerti keadaan orang lain.

\section{Aspek-Aspek Kecerdasan Emosional(7)}

\section{Mengenali Emosi Diri}

Mengenal emosi diri atau kesadaran diri yaitu kemampuan mengenali perasaan sewaktu perasaan itu terjadi. Kemampuan ini merupakan dasar kecerdasan emosional, 
dimana ketidakmampuan untuk mencermati perasaan yang sesungguhnya membuat diri berada dalam kekuasaan perasaan, sehingga tidak peka akan perasaan yang sesungguhnya yang berakibat buruk bagi pengambilan keputusan. Kesadaran diri merupakan syarat untuk mengendalikan emosi dimana dalam pembelajaran mahasiswa diharapkan mampu mengenali emosi seperti marah, sedih, gundah, bahagia, dan lain-lain.

\section{Mengelola Emosi}

Mengelola emosi adalah kemampuan menangani perasaan agar perasaan dapat terungkap secara pas. Dimana kemampuan ini bergantung pada kesadaran diri, yang meninjau kemampuan menghibur diri sendiri, melepaskan kecemasan, kemurungan, atau ketersinggungan. Individu yang buruk dalam kemampuan ini akan mengalami kesulitan melawan rasa murung, sementara individu yang pintar dalam kemampuan ini dapat bangkit kembali dengan jauh lebih cepat dari kemerosotan atau kejatuhan sebelumnya.

\section{Memotivasi Diri Sendiri}

Prestasi akan didapat bila individu memiliki motivasi dalam diri, yang berarti memiliki ketekunan untuk menahan diri terhadap kepuasan dan mengendalikan dorongan hati, serta mempunyai perasaan motivasi yang positif. Mampu menyesuaikan diri memungkinkan terwujudnya kinerja yang tinggi dalam segala bidang. Individu yang memiliki keterampilan ini cenderung jauh lebih produktif dan efektif disegala bidang.

\section{Mengenali Emosi Orang Lain}

Mengenali emosi orang lain atau empati merupakan kemampuan yang juga bergantung pada kesadaran diri emosional. Dimana individu yang empatik lebih mampu menangkap sinyal-sinyal sosial yang tersembunyi yang mengisyaratkan apa yang dibutuhkan atau dikehendaki orang lain.

\section{Membina Hubungan}

Kemampuan dalam membina hubungan merupakan suatu keterampilan yang menunjang popularitas, kepemimpinan dan keberhasilan antar pribadi. Keterampilan dalam berkomunikasi merupakan kemampuan dasar dalam keberhasilan membina hubungan. Individu sulit untuk mendapatkan apa yang diinginkannya dan sulit juga memahami keinginan serta kemauan orang lain.Orangorang yang hebat dalam keterampilan membina hubungan ini akan sukses dalam bidang apapun.

Dalam penelitian ini aspek yang dikembangkan adalah aspek yang dikemukakan oleh Goleman yang terdiri dari kesadaran diri emosional, mengelola emosi, membina hubungan, empati dan memanfaatkan emosi secara produktif.

Menurut Slameto yang dikutip oleh Sadudin dalam skripsinya menjelaskan minat adalah rasa lebih suka dan rasa ketertarikan pada suatu hal atau aktifitas tanpa ada yang menyuruh, minat pada dasarnya merupakan penerimaan akan sesuatu hubungan antara lain diri sendiri dengan sesuatu di luar diri, semakin kuat dan dekat hubungan tersebut maka semakin besar minat yang dimiliki.(10)

Berwirausaha adalah rasa lebih suka dan rasa ketertarikan pada suatu hal atau aktifitas tanpa ada yang menyuruh dan minat pada dasarnya merupakan penerimaan akan sesuatu hubungan antara lain diri sendiri dengan sesuatu di luar diri, semakin kuat dan dekat hubungan tersebut maka semakin besar minat yang dimiliki”.(5)

Berwirausaha adalah kemampuan untuk mengelola suatu aktivitas usaha yang memiliki kemampuan dalam menggunakan sumber daya finansial, bahan mentah dan tenaga kerja untuk menghasilkan sesuatu yang baru.

Minat berwirausaha adalah kecenderungan hati dan rasa ketertarikan terhadap aktivitas usaha dalam menggunakan sumber daya finansial, bahan mentah dan tenaga kerja untuk menghasilkan sesuatu yang baru.

Dalam berwirausaha seseorang disamping harus memiliki bakat, modal juga didorong oleh dua faktor yaitu faktor Internal dan faktor eksternal. faktor internal yang mendukung antara lain berfikir positif, kreatif, inisiatif, inovatif, disiplin,dan faktor eksternalnya adalah lingkungan fisik, dan lingkungan sosial.(10)

\section{Faktor internal}

Faktor-faktor yang berasal dari dalam yang dapat mendorong seseorang untuk berwirausaha, yaitu:

\section{a. Berfikir Positif}


Berfikir positif akan mengarahkan pada hal-hal yang membangun, menguntungkan sehingga akan tercipta perbaikan dan karyakarya baru yang bermanfaat bagi manusia.

\section{b. Kreatif}

Menciptakan produk baru dan cara baru merupakan bagian dari kreatifitas seseorang, sehingga kreatifitas dianggap sebagai penciptaan ide-ide baru.

\section{c. Inisiatif}

Inisiatif berarti memulai, yang dimaksud dengan memulai adalah tindakan awal yang akan dilakukan seseorang sehingga pekerjaan tersebut dapat terlaksana. Demikian juga dalam berwirausaha kesempatan untuk mendapatkan peluang pertama pada umumnya didapat oleh mereka yang berinisiatif untuk merespon terlebih dahulu setiap ide baru yang muncul.

\section{d. Disiplin}

Displin berkaitan dengan sikap dan kebiasaan yang langsung melekat pada diri seseorang. Seseorang yang mempunyai disiplin tinggi dalam melakukan usaha tidak hanya patuh dan taat pada hal-hal yang berhubungan dengan kewirausahaan, tetapi juga memiliki inisiatif untuk bertindak melakukan usaha yang lebih baik. Dengan disiplin yang tinggi akan mendorong seorang wirausahawan memiliki sikap tanggung jawab untuk perkembangan usahanya lebih lanjut.

\section{Faktor eksternal}

Faktor eksternal yang berasal dari luar yang dapat mendorong orang untuk berwirausaha, yaitu:

\section{a. Lingkungan fisik}

Manusia berusaha dan bekerja tidak lepas dari lingkungan di mana dia berada. Lingkungan alam, kekayaan alam, keadaan tanah dan sebagainya merupakan lingkungan fisik yang mendorong minat berwirausaha. Lingkungan alam yang berbeda-beda akan mendorong kegiatan wirausaha yang berbeda pula. Dengan pengenalan terhadap lingkungan fisik ini memungkinkan seseorang dapat memanfaatkan dan mendayagunakan secara efisien untuk kepentingan hidupnya.

\section{b. Lingkungan sosial}

Merupakan lingkungan masyarakat dimana terjadi interaksi antara individu satu dengan yang lain, individu dengan kelompok, atau kelompok dengan kelompok. Lingkungan sosial ini dapat terbagi menjadi dua yaitu lingkungan keluarga dan lingkungan masyarakat.

Menurut Winardi yang dikutip oleh Sadudin dalam skripsinya menyebutkan faktor-faktor yang mempengaruhi minat berwirausaha ada dua yaitu:(10)

\section{Faktor ekonomi}

Faktor ekonomi berisi segala hal yang berkaitan dengan perubahan ekonomi. Faktor ekonomi ini dibagi menjadi dua yaitu:

a. Adanya persediaan modal, artinya dengan adanya ketersediaan modal akan mendorong berdirinya perusahaan guna mendanai segala aktifitasnya.

b. Adanya perangsang pasar, artinya dengan adanya kebutuhan sosial baru dapat diupayakan dengan wirausaha akan memenuhi kebutuhan ekonomi.

\section{Faktor non ekonomi}

Faktor non ekonomi yaitu faktor yang tidak memiliki keterkaitan dengan perubahan ekonomi. Beberapa hal yang berkaitan misalnya yaitu mobilitas sosial, struktur hukum, dan lainnya. Dari pendapat yang telah peneliti kutip diatas maka dapat disimpulkan faktor yang mempengaruhi minat berwirausaha adalah faktor internal dan faktor eksternal yang disertai modal usaha dan terbukanya peluang untuk berwirausaha dan adanya kepastian hukum dan mobilitas sosial yang mendukung untuk berwirausaha.

\section{Metodologi Penelitian}

Tempat penelitian yaitu Universitas Darwan Ali Sampit yang beralamat di Jalan Batu Berlian No.10 Sampit, Kabupaten Kotawaringin Timur, Kalimantan Tengah. Penelitian ini dilaksanakan pada 3 April 2017 sampai dengan 5 Juni 2017. Jenis penelitian ini menggunakan pendekatan kuantitatif. Metode penelitian yang digunakan penulis adalah metode penelitian survei. Subjek dalam penelitian ini berjumlah 92 mahasiswa 
dengan pembagiannya dijelaskan pada tabel 1, sebagai berikut:

\section{Tabel 1: Subjek Penelitian}

\begin{tabular}{|r|r|c|} 
No & Semester/Ruang & $\begin{array}{c}\text { Jumlah } \\
\text { Mahasiswa }\end{array}$ \\
\hline 1. & VI A Siang & 35 orang \\
\hline 2. & VI C Malam & 32 orang \\
\hline 3. & VI D Malam & 25 orang \\
\hline & Total Mahasiswa & 92 orang \\
\hline
\end{tabular}

Definisi operasional variabel kecerdasan emosional, kecerdasan emosional adalah "kemampuan seperti kemampuan untuk memotivasi diri sendiri dan bertahan menghadapi frustasi, mengendalikan dorongan hati dan tidak melebih-lebihkan kesenangan, mengatur suasana hati dan menjaga agar beban stres tidak melumpuhkan kemampuan berpikir, berempati, dan berdoa", dan aspek kecerdasan emosional yaitu mengenali emosi diri, mengelola emosi, memotivasi diri sendiri, mengenali emosi orang lain, dan membina hubungan.(7)

Menurut Bhandari yang dikutip oleh Ariesta dalam skripsinya menjelaskan definisi operasional variabel minat berwirausaha adalah kecenderungan hati dan rasa ketertarikan terhadap aktivitas usaha dalam menggunakan sumber daya finansial, bahan mentah dan tenaga kerja untuk menghasilkan sesuatu yang baru. Minat berwirausaha dalam penelitian ini menggunakan aspek yang mencakup prestis sosial, tantangan pribadi, menjadi bos, inovasi, kepemimpinan, fleksibilitas dan keuntungan.(3)

Penelitian ini menggunakan skala likert dengan alternatif pilihan jawaban Sangat Setuju (SS), Setuju (S), Tidak Setuju (ST), dan Sangat Tidak Setuju (STS), melalui pernyataan favorable dan pernyataan unfavorable. Berikut adalah tabel skoring skala minat mahasiswa dalam berwirausaha dijelaskan pada tabel 2, sebagai berikut:

\section{Tabel 2: Skala Pengukuran}

\begin{tabular}{|c|c|c|}
\multirow{2}{*}{ Pernyataan } & \multicolumn{2}{c}{ Skor/Nilai } \\
\cline { 2 - 3 } & Favorable & Unfavorable \\
\hline Sangat Setuju (SS) & 4 & 1 \\
\hline Setuju (S) & 3 & 2 \\
\hline Tidak Setuju (TS) & 2 & 3 \\
\hline Sangat Tidak & 1 & 4 \\
\hline Setuju (STS) & & \\
\hline
\end{tabular}

Berdasarkan Tabel 2, dapat dilihat bahwa pada pernyataan favorable nilai bergerak dari empat sampai satu, sebaliknya pada pernyataan unfavorable nilai bergerak dari satu sampai empat.

Tabel 3: Blue Print Kecerdasan Emosional sebelum uji validitas

\begin{tabular}{|c|c|c|c|}
\hline \multirow{2}{*}{$\begin{array}{l}\text { Variabel } \\
\text { Penelitian }\end{array}$} & \multirow[t]{2}{*}{ Aspek } & \multicolumn{2}{|c|}{ Item/Butir Soal } \\
\hline & & Favorable & Unfavorable \\
\hline \multirow{5}{*}{$\begin{array}{l}\text { Kecerdasan } \\
\text { Emosional } \\
(\mathbf{X})\end{array}$} & $\begin{array}{l}\text { Mengenali } \\
\text { Emosi Diri }\end{array}$ & $1,2,3,4$ & 5,6 \\
\hline & $\begin{array}{l}\text { Mengelola } \\
\text { Emosi }\end{array}$ & $7,8,9,10,11$ & 12,13 \\
\hline & $\begin{array}{l}\text { Memotivasi } \\
\text { diri sendiri }\end{array}$ & $\begin{array}{l}14,15,16,1 \\
7\end{array}$ & 18 \\
\hline & $\begin{array}{l}\text { Mengenali } \\
\text { emosi orang } \\
\text { lain/empati }\end{array}$ & $\begin{array}{l}19,20,21,2 \\
2\end{array}$ & 23 \\
\hline & $\begin{array}{l}\text { Membina } \\
\text { hubungan }\end{array}$ & $\begin{array}{l}24,25,26,2 \\
7,28,29\end{array}$ & 30 \\
\hline
\end{tabular}

Total Item

30

Tabel 4: Blue Print Minat Berwirausaha sebelum uji validitas

\begin{tabular}{|c|c|c|c|}
\hline \multirow{2}{*}{$\begin{array}{l}\text { Variabel } \\
\text { Penelitian }\end{array}$} & \multirow[t]{2}{*}{ Aspek } & \multicolumn{2}{|c|}{ Item/Butir Soal } \\
\hline & & Favorable & Unfavorable \\
\hline \multirow{7}{*}{$\begin{array}{l}\text { Minat } \\
\text { berwirausaha }\end{array}$} & Prestis Sosial & $1,2,3$, & - \\
\hline & $\begin{array}{l}\text { Tantangan } \\
\text { Pribadi }\end{array}$ & $4,5,6$ & - \\
\hline & Menjadi Bos & $7,8,9$ & - \\
\hline & Inovasi & $10,11,12$ & - \\
\hline & Kepemimpinan & 13,14 & - \\
\hline & Fleksibilitas & 15,16 & - \\
\hline & Keuntungan & 17,18 & - \\
\hline \multicolumn{2}{|c|}{ Total Item } & & 18 \\
\hline
\end{tabular}


Berdasarkan Tabel 3 dan 4 , dapat dilihat bahwa dalam skala kecerdasan emosional terdapat $30 \mathrm{item} / \mathrm{butir}$ soal. Item tersebut terdiri dari 23 item favorable dan 7 item unfavorable. Sedangkan dalam skala minat berwirausaha terdapat 18 item/butir soal yang semuanya favorable.

Untuk menjamin validitas dan reliabilitasnya, instrument diuji dengan uji Validitas menggunakan corrected item-total dan uji reliabilitas cronbach's alpa. Dari hasil analisis didapat nilai Corrected item-total colerrelation yang kemudian nilai ini dibandingkan dengan nilai kritis $r$ tabel yaitu 0,30 . Berdasarkan hasil analisis didapat nilai korelasi untuk item 16 memiliki nilai Corrected item-total colerrelation $<0,30$ maka dapat disimpulkan bahwa item tersebut dinyatakan tidak valid, sehingga harus dikeluarkan. Sedangkan pada item-item lain yang nilainya lebih dari 0,30 dapat disimpulkan bahwa butir instrumen tersebut valid, dan dapat digunakan sebagai instrumen penelitian.

Tabel 5: Blue Print Kecerdasan Emosional Setelah uji validitas

\begin{tabular}{|c|c|c|c|}
\hline \multirow{2}{*}{$\begin{array}{l}\text { Variabel } \\
\text { Penelitian }\end{array}$} & \multirow[t]{2}{*}{ Aspek } & \multicolumn{2}{|c|}{ Item/Butir Soal } \\
\hline & & Favorable & Unfavorable \\
\hline \multirow{5}{*}{$\begin{array}{c}\text { Kecerdasan } \\
\text { Emosional } \\
\text { (X) }\end{array}$} & $\begin{array}{l}\text { Mengenali } \\
\text { Emosi Diri }\end{array}$ & 1,2 & 3 \\
\hline & $\begin{array}{l}\text { Mengelola } \\
\text { Emosi }\end{array}$ & $4,5,6$ & - \\
\hline & $\begin{array}{l}\text { Memotivasi } \\
\text { diri sendiri }\end{array}$ & $7,8,9,10$ & - \\
\hline & $\begin{array}{l}\text { Mengenali } \\
\text { emosi orang } \\
\text { lain/empati }\end{array}$ & $11,12,13$ & - \\
\hline & $\begin{array}{l}\text { Membina } \\
\text { hubungan }\end{array}$ & $\begin{array}{l}14,15,16 \\
17,18\end{array}$ & - \\
\hline \multicolumn{2}{|c|}{ Total Item } & \multicolumn{2}{|r|}{18} \\
\hline
\end{tabular}

Tabel 6: Blue Print Minat Berwirausaha Setelah Uji Validitas

\begin{tabular}{|c|l|c|c|}
\hline \multirow{2}{*}{$\begin{array}{l}\text { Variabel } \\
\text { Penelitian }\end{array}$} & \multicolumn{2}{|c|}{ Aspek } & \multicolumn{2}{c|}{ Item/Butir Soal } \\
\cline { 2 - 4 } $\begin{array}{c}\text { Minat } \\
\text { berwirausaha }\end{array}$ & Prestis Sosial & $1,2,3$, & - \\
\cline { 2 - 4 } & Tantangan Pribadi & $4,5,6$ & - \\
\cline { 2 - 4 } & Menjadi Bos & $7,8,9$ & - \\
\cline { 2 - 4 } & Inovasi & $10,11,12$ & - \\
\cline { 2 - 4 } & Kepemimpinan & 13,14 & - \\
\cline { 2 - 4 } & Fleksibilitas & 15, & - \\
\cline { 2 - 4 } & Keuntungan & 16,17 & - \\
\hline
\end{tabular}

Berdasarkan Tabel 5 dan 6, dapat dilihat bahwa hasil uji validitas dalam skala kecerdasan emosional, terdapat 18 item/butir soal yang dapat digunakan. Sedangkan dalam skala minat berwirausaha, terdapat 17 item/butir soal yang dapat digunakan sebagai instrumen penelitian.

\section{Tabel 7: Hasil Uji Reliabilitas Kecerdasan Emosional}

Reliability Statistics

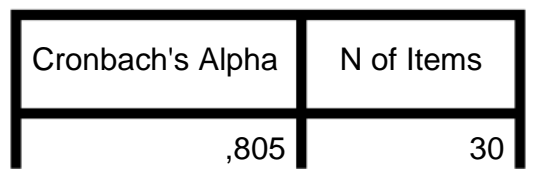

Dari hasil analisis di atas di dapat nilai Alpha sebesar 0,805 karena nilai Cronbach's Alpha lebih dari 0,6 maka dapat disimpulkan bahwa butir-butir instrumen kecerdasan emosional tersebut reliabel.

Tabel 8: Hasil Uji Reliabilitas Minat Berwirausaha

Reliability Statistics



Dari hasil analisis di atas di dapat nilai Alpha sebesar 0,915 karena nilai Cronbach's Alpha lebih dari 0,6 maka dapat disimpulkan bahwa butir-butir instrumen minat berwirausaha tersebut reliabel.

Untuk menganalisis data peneliti menggunakan Regresi Linier Sederhana 
dibantu software SPSS 15 for windows, dan pada model regresi ini ada uji asumsi yang perlu di lakukan sebelum melakukan analisis Regresi Linear sederhana yaitu terlebih dahulu melakukan uji normalitas, uji Linearitas, uji Autokorelasi.

\section{Analisis Regresi Linear Sederhana}

Rumus persamaan regresi Linear sederhana dapat dijabarkan sebagai berikut:

$\mathrm{Y}=\mathrm{a}+\mathrm{bX}$

Keterangan:

$\mathrm{Y}=$ Minat Berwirausaha

$\mathrm{X}=$ Kecerdasan Emosional

$\mathrm{a}=$ Konstanta (apabila nilai $\mathrm{X}=0$, maka $\mathrm{Y}$ akan sebesar a atau konstanta

$\mathrm{b}=$ Koefisien regresi

2. Uji Asumsi

a. Uji Normalitas

Uji normalitas digunakan untuk mengetahui apakah distribusi data tersebut normal atau tidak. Dalam penelitian ini pengujian normalitas menggunakan pendekatan kolmogorov smirnov.

Suatu data dapat dikatakan berdistribusi normal apabila signifikan atau nilai $\rho \geq 0,05$.

\section{b. Uji Linearitas}

Uji linieritas bertujuan untuk mengetahui apakah dua variabel mempunyai hubungan yang linear atau tidak secara signifikan. Uji ini digunakan sebagai prasyarat dalam analisis korelasi atau regresi linear. Dua variabel dikatakan mempunyai hubungan yang linear bila signifikansi (linearity) kurang dari 0,05.(9)

\section{c. Uji Autokorelasi}

Uji autokorelasi adalah menguji ada tidaknya korelasi antara kesalahan pengganggu pada periode tertentu dengan periode sebelumnya pada persamaan regresi linier. Untuk mendiagnosis adanya autokorelasi dalam suatu model regresi dilakukan melalui uji Durbin Watson. Uji Durbin Watson dapat dilakukan dengan bantuan SPSS 15 for windows. Adapun kriteria pengambilan keputusan yaitu: angka D- W dibawah -2 berarti ada autokorelasi positif dan angka D-W diantara -2 sampai +2 berarti tidak ada autokorelasi.(4)

3. Uji Hipotesis
Uji hipotesis dalam penelitian ini menggunakan uji t. Kriteria pengambilan keputusan untuk uji $t$ ini adalah sebagai berikut :

Jika $\mathrm{t}_{\text {hitung }} \leq$ dari $\mathrm{t}_{\text {tabel }}$ maka $\mathrm{H}_{\mathrm{o}}$ diterima

Jika $t_{\text {hitung }}>$ dari $t_{\text {tabel }}$ maka $\mathrm{H}_{\mathrm{o}}$ ditolak

$\mathrm{H}_{\mathrm{a}}=$ ada pengaruh positif antara kecerdasan emosional terhadap minat berwirausaha mahasiswa.

4. Koefisien Determinasi.

Analisis koefisien determinasi digunakan untuk mengetahui presentase sumbangan pengaruh variabel independen (X) secara serentak terhadap variabel dependen $(\mathrm{Y})$. Koefisien ini menunjukkan seberapa besar presentase variasi variabel independen yang digunakan dalam model mampu menjelaskan variasi variabel dependen. $R^{2}$ sama dengan 0 , maka tidak ada sedikitpun presentase sumbangan pengaruh yang diberikan variabel independen tehadap variabel dependen. Sebaliknya, $\mathrm{R}^{2}$ sama dengan 1 , maka presentase sumbangan pengaruh yang diberikan variabel independen terhadap variabel dependen adalah sempurna.(9)

\section{Hasil dan Pembahasan}

Hasil analisis data penelitian menunjukkan bahwa untuk variable Kecerdasan Emosionaldapat diketahui:

Tabel 9: Hasil Analis Data Variabel $X$

\begin{tabular}{|l|l|l|}
\hline & & VAR00001 \\
\hline N & Valid & 92 \\
\hline Mean & Missing & 0 \\
\hline Std. Error of Mean & & 56,3478 \\
\hline Median & &, 61387 \\
\hline Mode & & 56,0000 \\
\hline Std. Deviation & & 54,00 \\
\hline Variance & & 5,88803 \\
\hline Range & & 34,669 \\
\hline Minimum & & 32,00 \\
\hline Maximum & & 36,00 \\
\hline Sum & 25 & 68,00 \\
\hline Percentiles & 50 & 5184,00 \\
\hline & 75 & 53,0000 \\
\hline
\end{tabular}

Sumber: Data Primer diambil dari Output SPSS 
Variabel kecerdasan Emosional diperoleh skor minimum sebesar 36, skor maksimum sebesar 68, mean sebesar 56,3478 dan standar deviasi sebesar 5,88803. Berdasarkan skorskor tersebut maka akan dibuat kategorisasi. Tujuan kategorisasi adalah untuk menempatkan individu ke dalam kelompokkelompok yang terpisah secara berjenjang menurut suatu kontinum berdasarkan atribut yang diukur. Banyaknya jenjang kategorisasi diagnosis yang digunakan tidak melebihi lima jenjang tapi juga tidak kurang dari tiga jenjang. Penulis menetapkan tiga kategorisasi sesuai dengan tingkat diferensiasi yang dikehendaki, yaitu tinggi, sedang, dan rendah.

Setelah diketahui Mean ideal (Mi) dan Standar Deviasi (SDi), kemudian dapat disusun kriteria sebagai berikut:

$$
\begin{aligned}
& \text { Kriteria tinggi } \quad=\mathrm{X}>(\mathrm{Mi}+\mathrm{SDi}) \\
& =\mathrm{X}>(56,3478+5,88803) \\
& =X>62 \\
& \text { Kriteria sedang } \quad=(\mathrm{Mi}-\mathrm{SDi}) \leq \mathrm{X} \leq \\
& (\mathrm{Mi}+\mathrm{SDi}) \\
& =(56,3478-5,88803) \leq X \leq \\
& (56,3478+5,88803) \\
& =50 \leq \mathrm{X} \leq 62 \\
& \text { Kriteria rendah } \quad=\mathrm{X}<(\mathrm{Mi}-\mathrm{SDi}) \\
& =\mathrm{X}<(56,3478-5,88803) \\
& =\mathrm{X}<50
\end{aligned}
$$

Berdasarkan data tersebut di atas dapat dibuat kriteria kecenderungan sebagai berikut:

Tabel 10: Kriteria Variabel $X$ (Kecerdasan Emosional)

\section{No. Skor Frekuens Persen \% Kriteria i}

\begin{tabular}{|l|l|l|l|l}
\hline 1. & $\begin{array}{l}\mathrm{X} \\
>62\end{array}$ & 18 & 19,57 & Tinggi \\
\hline 2. & $\begin{array}{l}50 \leq \\
\mathrm{X} \leq\end{array}$ & 65 & 70,65 & Sedang \\
62 & & & \\
\hline
\end{tabular}

\begin{tabular}{|l|l|l|l|l|}
\hline $\begin{array}{l}\mathrm{X} \\
<50\end{array}$ & 9 & 9,78 & Rendah \\
\hline Total & 92 & 100 & \\
\hline
\end{tabular}

Sumber: Data primer yang telah diolah
Berdasarkan tabel diatas, maka dapat diketahui Kecerdasan Emosional pada kriteria rendah sebanyak 19,57\% kriteria sedang 70,65\% dan kriteria tinggi sebanyak 9,78\%. Dapat diambil kesimpulan bahwa kecenderungan Kecerdasan Emosional pada mahasiswa Univesitas Darwan Ali Sampit Tahun Akademik 2016/2017 adalah sedang.

Hasil analisis data menunjukkan bahwa untuk variabel Minat Berwirausaha (Y) dapat diketahui pada tabel:

\section{Tabel 11: Analisis Data Variabel Y}

\begin{tabular}{|l|c|c|}
\hline & & VAR00002 \\
\hline N & Valid & 92 \\
\hline & Missing & 0 \\
\hline Mean & & 57,7283 \\
\hline Std. Error of Mean & &, 77375 \\
\hline Median & & 59,0000 \\
\hline Mode & & 65,00 \\
\hline Std. Deviation & & 7,42154 \\
\hline Variance & & 55,079 \\
\hline Range & & 32,00 \\
\hline Minimum & & 36,00 \\
\hline Maximum & & 68,00 \\
\hline Sum & & 5311,00 \\
\hline Percentiles & 25 & 51,0000 \\
\hline & & 59,0000 \\
\hline & & 64,7500 \\
\hline & & \\
\hline
\end{tabular}

Sumber: Data Ouput SPSS

Djemari Mardapi dalam Sulistiyorini (2014: 62) Setelah diketahui Mean ideal (Mi) dan Standar Deviasi (SDi), kemudian dapat disusun kriteria sebagai berikut:

$$
\begin{aligned}
& \text { Kriteria tinggi } \quad=X>(\mathrm{Mi}+\mathrm{SDi}) \\
& =\mathrm{X}>(57,7283+7,42154) \\
& =\mathrm{X}>65
\end{aligned}
$$

$$
\begin{aligned}
& \text { Kriteria sedang } \quad=(\mathrm{Mi}-\mathrm{SDi}) \leq \mathrm{X} \leq \\
& (\mathrm{Mi}+\mathrm{SDi}) \\
& =(57,7283-7,42154) \leq \mathrm{X} \leq \\
& (57,7283+7,42154) \\
& =50 \leq \mathrm{X} \leq 65 \\
& \text { Kriteria rendah } \quad=\mathrm{X}<(\mathrm{Mi}-\mathrm{SDi}) \\
& =\mathrm{X}<(57,7283-7,42154) \\
& =\mathrm{X}<50
\end{aligned}
$$


Berdasarkan data tersebut di atas dapat dibuat kriteria kecenderungan sebagai berikut:

Tabel 12: Kriteria Variabel Y (Minat Berwirausaha)

\begin{tabular}{|c|c|c|c|c|}
\hline No. & Skor & Frekuensi & $\begin{array}{c}\text { Persen } \\
\%\end{array}$ & Kriteria \\
\hline 1. & $\mathrm{X}>65$ & 11 & 11,96 & Tinggi \\
\hline 2. & $\begin{array}{c}50 \leq \mathrm{X} \leq \\
65\end{array}$ & 62 & 67,39 & Sedang \\
\hline 3. & $\mathrm{X}<50$ & 19 & 20,65 & Rendah \\
\hline & Total & 92 & 100 & \\
\hline
\end{tabular}

Sumber: Data primer yang telah diolah

Berdasarkan tabel diatas, maka dapat diketahui Minat Berwirausaha pada kriteria rendah sebanyak 19 mahasiswa $(20,65 \%)$, kriteria sedang 62mahasiswa $(67,39 \%)$, dan kriteria tinggi sebanyak 11 mahasiswa $(11,96 \%)$. Dapat diambil kesimpulan bahwa kecenderungan Minat Berwirausaha mahasiswa di Universitas Darwan Ali Sampit Tahun Akademik 2016/2017 adalah sedang.

Sebelum menguji hipotesis dalam penelitian ini, terlebih dahulu dilakukan pengujian asumsi atau pengujian prasyarat analisis data yang meliputi:

\section{Uji Normalitas}

Pengujian normalitas data menggunakan pendekatan kolmogorov smirnov. Suatu data dapat dikatakan berdistribusi normal apabila signifikan atau nilai $\rho \geq 0,05$ (Sarwono dalam Primastuti Widyaningrum, 2013:52).

\section{Tabel 13: Hasil Uji Normalitas}

\begin{tabular}{|l|l|l|l|}
\hline & & VAR00001 & VAR00002 \\
\hline $\mathrm{N}$ & Mean & 52 & 92 \\
\hline $\begin{array}{l}\text { Normal } \\
\text { Parameters } \\
(\mathrm{a}, \mathrm{b})\end{array}$ & 56,3478 & 57,7283 \\
\hline & $\begin{array}{l}\text { Std. } \\
\text { Deviation }\end{array}$ & 5,88803 & 7,42154 \\
\hline $\begin{array}{l}\text { Most } \\
\text { Extreme }\end{array}$ & Absolute &, 078 &, 112 \\
\hline \begin{tabular}{l} 
Differences \\
\hline
\end{tabular} & Positive &, 074 &, 087 \\
\hline Nogative &,- 078 &,- 112 \\
\hline Asymp. Sig. (2-tailed) &, 625 & 1,070 \\
\hline
\end{tabular}

Sumber : Data Primer yang diambil dari Output SPSS

Dari tabel uji normalitas pada variabel $\mathrm{X}$ Kecerdasan Emosional mempunyai nilai $\mathrm{p}$ sebesar 0,625>0,05 dan Minat Berwirausaha (Y) mempunyai nilai $\mathrm{p}$ sebesar $0,203>0,05$ maka dapat disimpulkan bahwa sampel yang diambil berasal dari populasi yang berdistribusi normal.

\section{Uji Linearitas}

Uji linieritas digunakan untuk mengetahui apakah dua variabel mempunyai hubungan yang linear atau tidak secara signifikan. Dua variabel dikatakan mempunyai hubungan yang linear bila signifikansi (linearity) kurang dari 0,05 (Duwi Priyatno, 2010: 73).

Hasil uji linieritas pada variabel Kecerdasan Emosional dan Minat Berwirausaha terdapat nilai Signifikansi (p) sebesar $0,000<0,05$ maka dapat disimpulkan bahwa terdapat hubungan linier secara signifikan antara Kecerdasan Emosional (X) dengan Minat Berwirausaha (Y) sehingga dapat digunakan untuk analisis regresi linier.

\section{Autokorelasi}

Uji autokorelasi untuk menguji apakah dalam model regresi linier ada korelasi antara kesalahan pengganggu pada periode tertentu dengan kesalahan pada periode sebelumnya. Model regresi yang baik adalah regresi yang bebas dari autokorelasi atau tidak terjadi autokorelasi. Jika DW dibawah -2 berarti ada autokorelasi positif, jika DW diantara -2 sampai +2 berarti tidak ada autokorelasi, dan jika DW diatas +2 berarti ada autokorelasi negatif. Berdasarkan analisis data yang dilakukan dengan bantuan program SPSS 15 dengan melalui uji Durbin Watson (DW). Adapun hasil uji autokorelasi dapat dilihat pada tabel berikut:

\section{Tabel 14: Hasil Uji Autokorelasi}

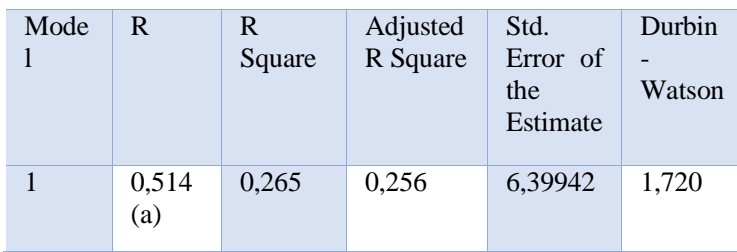

Sumber : Data Primer dari Output SPSS

Dari tabel uji autokorelasi pada variabel kecerdasan emosional dan minat berwirausaha menunjukkan nilai Durbin 
Watson (DW) sebesar 1,720 diantara -2 sampai +2 maka dapat disimpulkan bahwa variabel bebas dan variabel terikatnya tidak terdapat autokorelasi.

1. Analisis Regresi Sederhana dan Uji Hipotesis

a. Persamaan Regresi

Penjelasan tentang hasil pengujian hipotesis dalam penelitian ini yaitu hipotesis menyatakan bahwa ada pengaruh Kecerdasan Emosional Terhadap Minat Bewirausaha Mahasiswa VI Sistem Informasi Prgram Studi Sistem Informasi Universitas Darwan Ali Sampit Tahun Akademik 2016/2017. Teknik analisis yang digunakan untuk menguji hipotesis dengan analisis regresi sederhana.

Tabel 15: Hasil Persamaan Regresi

\section{Coefficients (a)}

\begin{tabular}{|c|c|c|c|c|c|c|}
\hline Variabel & Konstanta & Koefisien & $\mathbf{r}^{2}$ & $\mathbf{t}_{\text {Hitung }}$ & $\mathbf{t}_{\text {Tabel }}$ & Sig \\
\hline $\mathbf{X}-\mathbf{Y}$ & 21,191 & 0,648 & 0,265 & 5,691 & 1,986 & 0,0 \\
\hline
\end{tabular}

Sumber : Data Primer yang diolah

Persamaan garis regresi dapat dinyatakan dalam persamaan sebagai berikut:

$$
\begin{aligned}
& Y=a+b X \\
& Y=21,191+0.648 X
\end{aligned}
$$

Koefisien regresi variabel kecerdasan emosional (X) sebesar 0,648, artinya jika kecerdasan emosional mengalami kenaikan sebesar 1, maka minat berwirausaha $(\mathrm{Y})$ akan mengalami peningkatan sebesar 0,648. koefisien bernilai positif artinya terjadi hubungan positif antara kecerdasan emosional dengan minat berwirausaha, semakin tinggi kecerdasan emosional, semakin tinggi pula minat berwirausahanya.

\section{b. Uji Hipotesis}

Uji ini menggunakan Uji t. Uji ini digunakan untuk mengetahui apakah variabel independen $\mathrm{X}$ berpengaruh secara signifikan terhadap variabel dependen $(\mathrm{Y})$.

Kriteria pengambilan keputusan untuk uji $\mathrm{t}$ ini adalah sebagai berikut :

Jika $t_{\text {hitung }} \leq$ dari $t_{\text {tabel }}$ maka $\mathrm{H}_{\mathrm{o}}$ diterima
Jika $\mathrm{t}_{\text {hitung }}>$ dari $\mathrm{t}_{\text {tabel }}$ maka $\mathrm{H}_{\mathrm{o}}$ ditolak

$\mathrm{H}_{\mathrm{a}}=$ ada pengaruh kecerdasan emosional terhadap minat berwirausaha mahasiswa semester VI Jurusan Sistem Informasi Program Studi Sistem Informasi Universitas Darwan Ali Sampit

Tabel 7.8 menunjukan hasil dari uji hipotesis kecerdasan emosional terhadap minat berwirausaha mahasiswa.

\section{Tabel 16: Hasil Uji Hipotesis}

\begin{tabular}{l|l} 
Nilai $\mathbf{t}_{\text {Hitung }}$ & Nilai $\mathbf{t}_{\text {Tabel }}$ \\
\hline $\mathbf{5 , 6 9 1}$ & 1,986 \\
\hline
\end{tabular}

Dari tabel di atas menunjukan bahwa nilai $\mathrm{t}_{\text {hitung }}>$ dari $\mathrm{t}_{\text {tabel, }}$ yaitu 5,691>1,986 berati $\mathrm{H}_{\mathrm{o}}$ ditolak dan diterimanya $\mathrm{H}_{\mathrm{a}}$. Artinya ada pengaruh yang signifikan antara kecerdasan emosional terhadap minat berwirausaha mahasiswa semester VI Jurusan Sistem Informasi Program Studi Sistem Informasi Universitas Darwan Ali Sampit Tahun Akademik 2016/2017.

\section{c. Koefisien Determinasi}

Koefisien determinasi pada regresi linear sering diartikan sebagai seberapa besar kemampuan semua variabel bebas dalam menjelaskan varians dari variabel terikatnya. Berdasarkan hasil analisis dengan menggunakan SPSS 15 for Windows menunjukkan bahwa nilai koefisien determinasi $\left(r^{2}\right)$ sebesar 0,218.

\begin{tabular}{|c|c|c|c|c|c|}
\hline Model & $\mathbf{R}$ & $\begin{array}{l}\text { R } \\
\text { Squar } \\
\text { e }\end{array}$ & $\begin{array}{l}\text { Adjusted } \\
\text { R } \\
\text { Square }\end{array}$ & $\begin{array}{l}\text { Std. } \\
\text { Error of } \\
\text { the } \\
\text { Estimate }\end{array}$ & $\begin{array}{l}\text { Durbin- } \\
\text { Watson }\end{array}$ \\
\hline 1 &, $514(a)$ & 0,265 & ,256 & 6,39942 & 1,720 \\
\hline
\end{tabular}

\section{Tabel 17: Nilai koefisien determinasi}

Sumber : Data Primer dari Output SPSS

Dari tabelanalisis menunjukan bahwa nilai $R$ square adalah sebesar 0,265 atau 26,5\%, artinya pengaruh kecerdasan emosional terhadap minat berwirausaha mahasiswa adalah sebesar 26,5 \% dan 73,5 \%minat berwirausha dipengaruhi oleh faktor lain.

Berdasarkan hasil analisis data penelitian yang telah dilakukan,Hasil penelitian menunjukan bahwa kecerdasan emosional berpengaruh terhadap minat berwirausaha mahasiswa. Hasil penelitian ini juga sesuai 
dengan hasil penelitian yang relevan. Seperti penelitian yang dilakukan Then Nana Universitas Atma Jaya pada tahun 2009 dengan judul pengaruh kecerdasan emosional terhadap minat berwirausaha mahasiswa program studi Manajemen Universitas Atma Jaya Yogyakarta menunjukan bahwa kecerdasan emosional berpengaruh signifikan terhadap minat berwirausaha.(8) Selanjutnya berdasarkan penelitian yang dilakukan oleh Muhamad Sadudin mengenai pengaruh kecerdasan emosional terhadap minat berwirausaha yang menunjukan bahwa kecerdasan emosional berpengaruh siknifikan terhadap minat berwirausahaan.(10) Dalam kewirausahaan membutuhkan suatu kecerdasan dalam pencarian informasi guna mengidentifikasi peluang-peluang yang ada dan kemampuan untuk berbenah diri dalam mengatasi segala resiko. Hal tersebut dapat dilakukan oleh seseorang dengan perkembangan emosi dan intelektual yang baik. Dari hasil tersebut dapat disimpulkan bahwa kecerdasan emosional berpengaruh terhadap minat berwirausaha mahasiswa.

Dari hasil uji determinasi didapatkan nilai $\mathrm{R}^{2}=0,265$. Hal tersebut menunjukan bahwa kecerdasan emosional berpengaruh positif terhadap minat berwirausaha mahasiswa. semakin tinggi kecerdasan emosional yang dimiliki mahasiswa, maka semakin tinggi pula minat berwirausaha.

\section{Kesimpulan}

Berdasarkan hasil penelitian yang telah dilakukan, maka penulis dapat menarik simpulan bahwaada pengaruh kecerdasan emosional terhadap minat berwirausaha mahasiswa semester VI Jurusan Sistem Informasi Program Studi Informasi Universitas Darwan Ali Sampit Tahun Akademik 2016/2017. Dengan demikian kecerdasan emosional dapat menumbuhkan minat berwirausaha mahasiswa semester VI Jurusan Sistem Informasi Program Studi
Sistem Informasi Universitas Darwan Ali Sampit Tahun Akademik 2016/2017.

\section{Daftar Pustaka}

1. Agustian AG. Rahasia Sukses Membangun Kecerdasan Emosional Spiritual ESQ. Jakarta: PT Arga Tilanta, 2010.

2. Al Hajjaj YA. Agar Anda Menjadi Jauh Lebih Cerdas. Surakarta: Al Jadid, 2009.

3. Ariesta E. Minat Mahasiswa Dalam Berwirausaha "Studi Kasus pada Mahasiswa Manajemen Unika Soegijapranata [Online]. Prodi Manajemen Unika Soegijapranata: 2010. http://repository.unika.ac.id/8667/ [28 Mar. 2018].

4. Arikunto S. Prosedur Penelitian: Suatu Pendekatan Praktik. Jakarta: Rineka Cipta, 2006.

5. Bukhari A. Kewirausahaan. Bandung: Alfabeta, 2011.

6. Depdiknas RI. Undang-Undang Pendidikan Nasional Republik Indonesia Nomor 20 Tahun 2003 Tentang Sistem Pendidikan Nasional. Jakarta: Departemen Pendidikan Nasional Republik Indonesia, [date unknown].

7. Goleman D. Emotional Intelligence. Jakarta: PT Gramedia Pustaka Utama, 2015.

8. Nana T. Pengaruh Kecerdasan Emosional Terhadap Minat Berwirausaha Mahasiswa Program Studi Manajemen Universitas Atma Jaya Yogyakarta [Online]. UAJY: 2009. http://e-journal.uajy.ac.id/2750/ [29 Mar. 2018].

9. Priyanto D. Paham Analisa Statistik Data Dengan SPSS. Jogyakarta: Mediakom, 2010.

10. Sadudin M. Pengaruh Kecerdasan Emosional Terhadap Minat Berwirausaha Mahasiswa. Sekolah Tinggi Keguruan Ilmu Pendidikan Muhammadiyah: 2015.

11. Sari EV. Ekonomi Melambat, Pengangguran Indonesia Bertambah [Online]. CNN Indonesia: [date unknown]. https://www.cnnindonesia.com/ekonomi/201 50505150630-78-51318/ekonomi-melambatpengangguran-indonesia-bertambah [27 Mar. 2018]. 